\title{
KEPEMIMPINAN WANITA PADA WILAYAH PUBLIK
}

\author{
Nur Rakhmi Said, S. Sos., MH \\ Balai Rehabilitasi BNN Baddoka Makassar \\ Snurrakhmi20@gmail.com
}

\section{Abstrak}

Pembahasan tentang kepemimpinan seorang wanita sampai saat ini menjadi salah satu topik yang hangat diperbincangkan di berbagai kalangan. Betapa tidak, dibeberapa daerah kabupaten dan kota maupun pada tingkat propinsi ditemukan beberapa calon pasangan yang mengajukan diri untuk menjadi pemimpin. Bahkan Indonesia sendiri pernah dipimpin oleh presiden wanita, Megawati Sukarno Putri, putri dari Presiden pertama Indonesia yaitu Soekarno. Dengan naiknya presiden wanita ini, desas desus pernyataan dan pertanyaan masyarakat terus berhembus, masyarakat dari yang berpendidikan bahkan sampai masyarakat awam pada saat itu banyak yang tiba-tiba menjadi mufti. Mengungkapkan pendapat dan pandangan terhadap kepemimpinan Megawati sebagai Presiden pertama wanita di Indonesia. lalu sebenarnya bagaimana hukumnya Islam memandang perihal kepemimpinan wanita, dan bagaimana pandangan ulama terhadap kepemimpinan wanita dalam wilayah publik. Inilah yang menjadi topik pembahasan yang penulis mencoba untuk mengupasnya.

Keyword: Kepemimpinan, Wanita, Wilayah Publik. 


\section{A. Latar Belakang}

Berbicara mengenai kepemimpinan maka pandangan masyarakat identik dengan gender lelaki yang dianggap sebagai simbol pada pemberian label pemimpin. Hal ini tidaklah keliru melihat dari segi perjalan sejarah kepemimpinan umat Islam, yang menjadi pemimpin adalah seorang lelaki. Kepemimpinan untuk membawa risalah kenabian dan kerasulan bahkan diberikan kekhususan oleh Allah kepada kaum lelaki untuk disampaikan kepada umat manusia.

Nabi Muhammad Saw. sebagai panutan dan teladan umat Islam yang merupakan khalifah yang memiliki peran juga sebagai pemimpin, ketika meinggal penerus kekhalifahannya juga merupakan seorang lelaki. Hal ini yang terkadang menjadi contoh yang menjadi dasar bahwa kepemimpinan ada pada pundak gender lelaki. Negara Indonesia yang merupakan Negara dengan mayoritas muslim juga memegang pandangan demikian, bahkan kondisi sosio kultural Indonesia yang patriarki juga seakan menegaskan bahwa yang menjadi seorang pemimpin adalah seorang lelaki. ${ }^{1}$

Seiring perkembangan ilmu pengetahuan dan teknologi memicu manusia untuk selalu mengembangkan dirinya. Potensi-potensi yang ada dalam diri seseorang menjadi modal besar dalam pembentukan sumber daya manusia yang produktif. Tidak hanya semua ini dilakukan oleh para kaum pria tapi juga kaum wanita mulai berkiprah dalam mencapai tujuannya, khususnya dalam lingkungan publik. Fakta yang kita temui saat ini bahwa wanita juga turut mengambil peran kepeminmpjnan ini. Hal ini seakan menimbulkan pertanyaan apakah wanita dapat menjadi pemimpin dalam wilayah publik sedangkan masih ada kaum lelaki yang masih dapat mennduduki jabatan sebagai pemimpin. Terdapat teks-teks

1 Karim, Khalil Abdul, Kontroversi Negara Islam (Surabaya: Nusantara Press, 2015), Hlm. 260. 
normatif memberikan beberapa interpretasi tentang boleh tidaknya seorang wanita berkiprah dalam urusan publik. Beberapa nash Al Quran dan hadits mengemukakan kedudukan wanita dan dinyatakan bahwa Islam sangat menjunjung tinggi harkat dan martabat wanita. Tidak ada diskriminasi antara pria dan wanita dalam nilai kemanusiaannya sebagai sesama manusia dan sebagai hamba Allah Swt. ${ }^{2}$

\section{B. Kepemimpinan Menurut Pandanagan Islam}

Menurut pandangan Islam mengenai akepemimpinan dapat dipahami melalui nash Al Quran dan hadits. Adapun bebrapa nash yang memberikan indikasi mengenai kepemimpinan dalaam Islam antara lain pada QS. Al Nisa: 58 berikut ini:

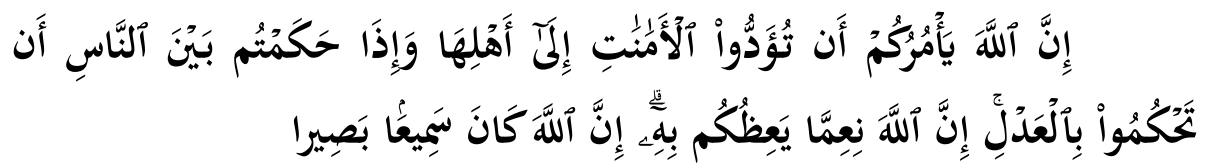

Terjemahnya:

"Sesungguhnya Allah menyuruh kamu menyampaikan amanat kepada yang berhak menerimanya, dan (menyuruh kamu) apabila menetapkan hukum di antara manusia supaya kamu menetapkan dengan adil. Sesungguhnya Allah memberi pengajaran yang sebaik-baiknya kepadamu. Sesungguhnya Allah adalah Maha mendengar lagi Maha Melihat."3

Imam Qurtubi memberikan penjelasan tentang ayat ini sebagai ummahat al-ahkam, mencakup sebagian besar persoalan

2 Rachmat Ramadhana al-Banjari, Prophetic Leadership (Cet. I; Yogyakarta: Diva Press, 2008), Hlm. 85.

${ }^{3}$ Kementrian Agama, Al-Qur'an Translitersi dan Terjemahnya Dilengkapi Dengan Fadhillah Amal (Bandung: PT. Sygma Examedia Arkanleema, 2011), Hlm. 78.

Sangaji Jurnal Pemikiran Syariah dan Hukum 
agama. Ayat ini menunjukan pada semua pemimpin agar jujur dan adil dalam pembagian harta, hingga tercipta kebijakan sesuai dengan kemaslahatan mereka. ${ }^{4}$ Untuk dapat memahami penjelasan di atas, dapat pula dilihat pada QS. Al An'am: 152 berikut ini:

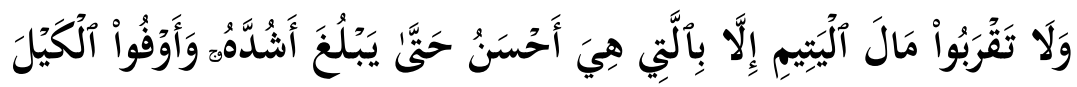

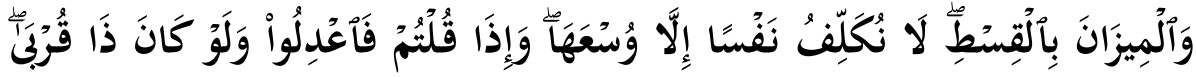

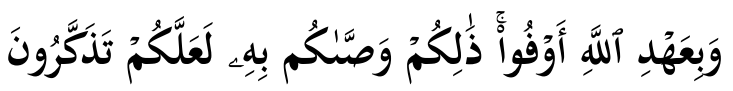

Terjemahnya:

"Dan janganlah kamu dekati harta anak yatim, kecuali dengan cara yang lebih bermanfaat, hingga sampai ia dewasa. dan sempurnakanlah takaran dan timbangan dengan adil. kami tidak memikulkan beban kepada sesorang melainkan sekedar kesanggupannya. dan apabila kamu berkata, Maka hendaklah kamu berlaku adil, kendatipun ia adalah kerabat(mu, dan penuhilah janji Allah. yang demikian itu diperintahkan Allah kepadamu agar kamu ingat." 5

Selain dari nash Al Quran di atas, kita juga dapat mengambil pemahaman mengenai kepemimimpinan dlam Islam melaui hadits. Berikut ini bebrapa hadits yang dapat kita ambil pemahaman di dalamnya.

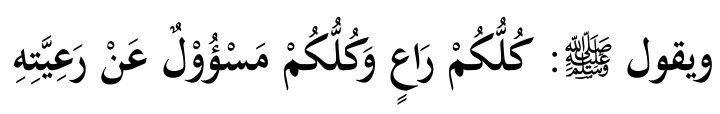

${ }^{4}$ Imam al-Qurtubi, Al-Jami' li ahkam al-Qur'an jil. 9 (t.t: t.p, t.tHlm.), Hlm. 255-256.

${ }^{5}$ Kementrian Agama, Al-Qur'an Translitersi dan Terjemahnya Dilengkapi Dengan Fadhillah Amal, Hlm. 149. 
Artinya:

"Setiap di antara kalian adalah pemimpin bertanggung jawab atas bawahannya."

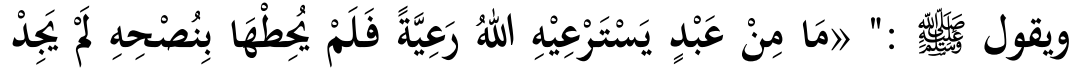

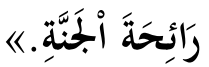

Artinya:

"Tidaklah seorang yang diberikan amanah untuk memimpin kemudian dia tidak menggunakannya dengan kebaikan maka tidak merasakan bau surga."7

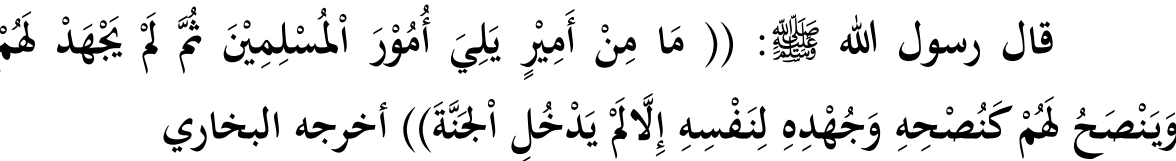

Artinya:

"Tiadalah seorang pemimpin muslim kemudian tidak berjuang untuk mereka dan tidak memberikan nasihat yang baik kecuali tidak akan memasuki surga."

Berbagai dalil tersebut di atas memberikan indikasi mengenai kriteria pemimpin. Beberapa poin dalam uraian di atas memberikan pemahaman bahwa:

1. Setiap orang adalah pemimpin sehingga siapapun juga bisa menjadi pemimpin

2. Seorang pemimpin harulah orang yang dapat bersifat adil

3. Kejujuran adalah salah satu sifat yang harus dimiliki oleh seorang pemimpin

4. Seorang pemimpin haruslah dapat menjalankan amanah dan dapat memberikan pembelajaran yang baik bagi orangorang yang berada di bawah kepemimpinanannya.

${ }^{6}$ HR. Bukhari, Shahih al-Bukhari Juz 8 (Damaskus: Dar al-Kutub alIlmiyah, t.tHlm.), Hlm. 108.

${ }^{7}$ HR. Bukhari, Shahih al-Bukhari Juz 8, No. 7150.

Sangaji Jurnal Pemikiran Syariah dan Hukum 
Beberapa poin di atas tergambar dalam sosok kepemimpinan Nabi Muhammad saw dengan sifatnya: Tabligh, siddiq, amanah dan fathanah sehingga dengan melihat landasan tersebut, penulis berpandangan bahwa kepemimpinan menurut Islam menekankan pada sifat yang harus dimilki oleh seorang pemimpin yaitu adil, jujur, dapat menjalankan amanah serta dapat menyampaikan segala bentuk kebaikan kepada orang yang dipimpinnya dalam menjalankan kewajiban dalam bermar ma'ruf nahi mungkar. Semakin besar tanggung jawab sebagai seorang pemimpin, maka semakin luas pula amah dan tugas beramar ma'ruf nahi mungkar tersebut harus dijalankan seorang pemimpin sehingga kriteria di atas sangatlah ditekankan dalam Islam sebagai dasar menjadi seorang pemimpin.

\section{Dalil-Dalil Mengenai Kepemimpinan Wanita dalam Wilayah Publik}

\section{Dalil berdasarkan petunjuk al Qur'an}

Berkaitan dengan kepemimpinan terutama dalam wilayah publik, ayat berikut merupakan ayat yang sering dijadikan landasan sebgai patron dalam mengeluarkan tafsiran berupa pendapat mengenai boleh atau tidaknya wanita menduduki posisi sebagai seorang pemimpin, dalil tersebut adalah QS. Al Nisa: 37 berikut ini:

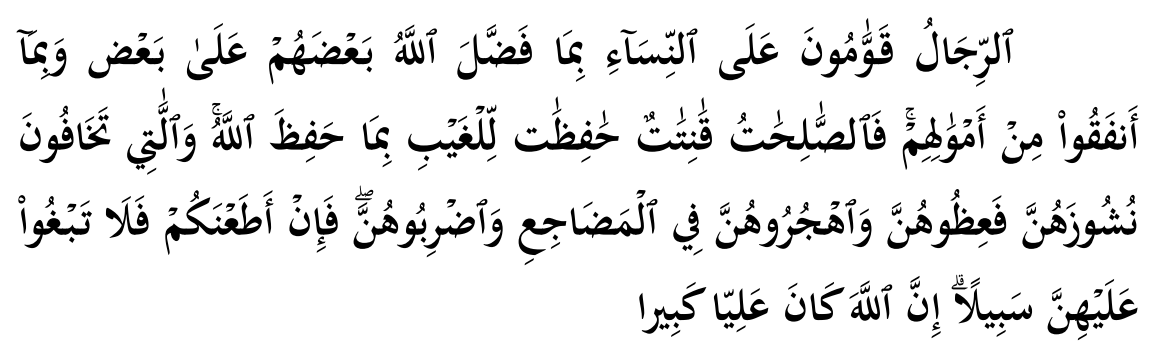


Terjemahnya:

"Kaum laki-laki itu adalah pemimpin bagi kaum wanita, oleh Karena Allah Telah melebihkan sebahagian mereka (lakilaki) atas sebahagian yang lain (wanita), dan Karena mereka (laki-laki) Telah menafkahkan sebagian dari harta mereka. sebab itu Maka wanita yang saleh, ialah yang taat kepada Allah lagi memelihara diri ketika suaminya tidak ada, oleh Karena Allah Telah memelihara (mereka). wanita-wanita yang kamu khawatirkan nusyuznya, Maka nasehatilah mereka dan pisahkanlah mereka di tempat tidur mereka, dan pukullah mereka. Kemudian jika mereka mentaatimu, Maka janganlah kamu mencari-cari jalan untuk menyusahkannya. Sesungguhnya Allah Maha Tinggi lagi Maha besar". ${ }^{8}$

\section{Dalil berdasarkan petunjuk haditst}

Berikut ini hadits mengenai pengangkatan Ratu persa bernama Bintu Kisra sebagai seorang pemimpin yang dapat dijadikan slaah satu pijakan mengenai kepemimpinan perempuan dalam wilayah publik.

حدثنا عثمان بن الهيثم حدثنا عوف عن الحسن عن أبي بكرة قال:

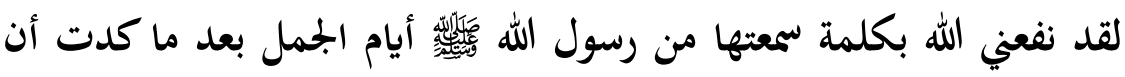

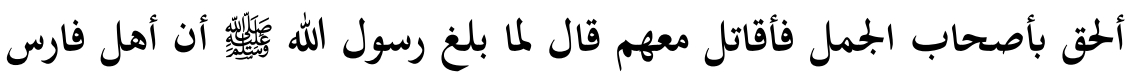
قد ملكوا عليهم بنت كسرى قال (لن يفلح قوم ولوا أمرهم امرأة). 9

Artinya:

Utsman ibn al-Hislam menceritakan kepada kami, 'Auf menceritakan kepada kami dari Hasan dari Abi

${ }^{8}$ Kementrian Agama, Al-Qur'an Translitersi dan Terjemahnya Dilengkapi Dengan Fadhillah Amal, Hlm. 78.

$9 \mathrm{Abu}$ 'Abdillah Muhammad ibn Isma'il al-Bukhari, shahih al-Bukhari, Juz. IV (Cet. III; Bairut: Dar Ibn Katsir, 1407 H/1987 M), Hlm. 1610.

Sangaji Jurnal Pemikiran Syariah dan Hukum 
Bakrah berkata: Allah telah memberiku manfaat dengan kalimat yang aku dengar dari Rasulullah saw. pada perang jamal setelah saya hampir ikut serta dalam perang jamal lalu berperang bersama mereka. Abi Bakrah berkata "ketika sampai berita kepada Rasululah saw bahwa penduduk Persia telah mengangkat bintu Kisra sebagai ratu. Rasulullah berkata: tidak akan sukses suatu kaum jika mereka dipimpin oleh seorang wanita.

\section{Pandangan Ulama Mengenai Kepemimpinan Wanita dalam Wilayah Publik}

\section{Pandangan Ulama Klasik}

Jumhur ulama memahami hadits kepemimpinan wanita secara tekstual. Mereka berpendapat bahwa berdasarkan petunjuk hadits tersebut pengangkatan wanita menjadi kepala negara, hakim pengadilan dan berbagai jabatan politis lainnya, dilarang. Selanjutnya, mereka menyatakan bahwa wanita menurut syara' hanya di beri tanggung jawab untuk menjaga harta suaminya. Oleh karenanya, Al Khattabi misalnya, mengatakan hawa seorang wanita tidak sah menjadi khalifah. ${ }^{10}$ Demikian pula Al Syaukani dalam menafsirkan hadits tersebut berpendapat bahwa wanita itu tidak termasuk ahli dalam hal kepemimpinan, sehingga tidak boleh menjadi kepala negara. ${ }^{11}$ Sementara itu, para ulama lainnya seperti Ibn Hazm, Al Ghazali meskipun dengan alasan yang berbeda juga mensyaratkan laki-laki sebagai kepala negara.

Jika diamati secara tekstual hadits diatas dinyatakan bahwa suatu negara tidak akan menuai keberhasilan dan

${ }^{10}$ Lihat: Ibn Hajar al-Asqalani, Tahzib al-Tahzib, Cet. I; Beirut: Dar al-Fikr, 1404 HLM./1984 M, Juz VII, Hlm. 128.

11 Muhammad ibn 'Ali ibn Muhammad al-Syaukani, Nail al-Autar, Jux VII (Mesir: Mustafa al-Babi al-Halabi, t.t.) , Hlm. 298. 
kesuksesan apabila yang memimpin mereka adalah seorang wanita. Pemahaman seperti itu akan berimplikasi pada pendeskriditan secara besar-besaran terhadap kualitas kaum wanita, sehingga dia tidak mempunyai hak sama sekali untuk mengatur negara.

Selain itu, ada juga ulama yang menyatakan bahwa wanita tidak layak menjadi pemimpin karena kurang dan lemah akalnya sedangkan kepemimpinan membutuhkan sebuah kemampuan besar untuk keluar mengurusi umat dan wanita adalah aurat sehingga ia tidak layak menjadi pemimpin maupun hakim. ${ }^{12}$ Selain itu, unsur kepemimpinan pada masa Rasulullah adalah sebagai pemimpin Negara, pemimpin shalat dan panglima perang. Sedangkan wanita tidak dapat memenuhi ketiga unsur kepemimpinan tersebut.

Adanya larangan wanita menjadi pemimpin disinyalir dari interpretasi sebagian ulama yang berlandaskan pada nash Al Quran surah al Nisa' di atas bahwa laki-laki adalah pemimpin bagi kaum wanita.

\section{Pandangan Ulama Kontemporer}

Sebagian ulama kontemporer memberikan pandangan berbeda mengenai penafsiran surah al Nisa di atas. Alasan-alasan yang diajukannya antara lain pertama, bahwa ayat ini berbicara tentang wilayah domestik, sehingga tidak bisa menjadi dasar bagi kepemimpinan yang berada di wilayah publik. Kedua, bahwa ayat ini tidak bersifat normatif tetapi bersifat informatif tentang situasi dan kondisi masyarakat Arab (dunia) saat itu, sehingga tidak memilki konsekwensi hukum. Ketiga, karena ada sejumlah ayat lain yang mengindikasikan kebolehan kepemimpinan wanita seperti dalam surat al Taubah ayat 71

12 Abd al-Rauf al-Manawi, Faid\{ al-Qadir, Juz V (Cet. I; Bairut: Dar alKutub al-'Ilmiyah, 1415 HLM./1994 M), Hlm. 386.

Sangaji Jurnal Pemikiran Syariah dan Hukum 
yang memberikan hak wilayah kepada wanita atas laki-laki. Kata wilayah bisa berarti penguasaan, kepemimpinan, kerja sama dan saling tolong menolong. Keempat, rijal dalam ayat ini tidak berarti jenis kelamin laki-laki, tetapi sifat-sifat maskulinitas yang bisa dimiliki oleh laki-laki dan wanita. ${ }^{13}$

Ulama kontemporer berusaha memahami hadits ini secara konteks, hal ini dikarenakan jika di lihat secara langsung terdapat pemahaman yang seakan-akan kontradiktif sehingga membutuhkan adanya sinkronisasi pemahaman. Sebelumnya perlu diketahui latar belakang historis munculnya hadits ini yang mana ketika Nabi Saw. menyampaikan hadits ini sebelumnya mendapatkan informasi bahwa seorang wanita (Bintu Kisra) telah diangkat menjadi pemimpin oleh negeri Persia menggantikan ayahnya. Padahal pada saat itu keberadaan wanita sebagai pemimpin masih dinafikan, yang berhak menjadi pemimpin adalah laki-laki. Tentu hal ini menyalahi tradisi yang ada pada saat itu. Disamping itu, kemampuan yang dimiliki wanita tidak sama dengan laki-laki, wanita Arab pada saat itu hanya mengurusi masalah keluarga dan tidak dipercaya menangani urusan umum atau kenegaraan dan memang tidak memiliki kapasitas keilmuan dalam wilayah publik. Dalam kondisi kerajaan Persia dan setting sosial seperti itulah, wajar Nabi Saw. yang memiliki kearifan tinggi, melontarkan hadits bahwa bangsa yang menyerahkan masalah-masalah (kenegaraan dan kemasyarakatan) kepada wanita tidak akan sukses. ${ }^{14}$ Disamping itu, mereka juga berpendapat bahwa ketika Nabi Saw. menyampaikan hadits tersebut tidak dalam kapasitas sebagai Nabi atau Rasul, akan tetapi perlu dipahami bahwa menyampaikannya

${ }^{13}$ Dikutip dari www.index.php.com. Diakses pada tanggal 10 Mei 2017

14 Ali, Nizar, Hadis Versus Sains: Memahami Hadis-Hadis Musykil (Cet. I; Yogyakarta: Penerbit Teras, 2008), Hlm. 117. 
dalam kapasitasnya sebagai manusia biasa atau sebagai pribadi yang menginformasikan realitas sosial pada saat itu dan untuk mengantisipasi kemungkinan yang terjadi jika kepemimpinan itu diserahkan kepada wanita. ${ }^{15}$ Ada juga ulama kontemporer yang mengemukakan kebolehan kaum wanita menjadi pemimpin. Namun, ia dapat memimpin jika memiliki kemampuan dan keahlian yang sama dengan kemampuan yang dimiliki oleh laki-laki. ${ }^{16}$ Syuhudi Ismail berpendapat bahwa ketika wanita telah memiliki kewibawaan dan kemampuan untuk memimpin, serta masyarakat bersedia menerimanya sebagai pemimpin, maka tidak ada salahnya wanita di pilih dan di angkat sebagai pemimpin. ${ }^{17}$ Pendapat lain juga menyatakan bahwa wanita sah-sah saja menjadi kepala Negara jika bukan kekuasaan tertinggi. Artinya, masih ada lembaga di atas kepala Negara atau presiden.

Dengan beberapa argumen/pernyataan yang dikemukakan oleh ulama kontemporer di atas dapat dipahami bahwa hadits mengenai larangan wanita menjadi pemimpin tidak terkait dengan wacana persyaratan syar'i bagi seorang pemimpin. Beliau hanya merespon pengangkatan Ratu Persia. Namun, ada beberapa hal yang menjadi kemungkinan jika hal ini dikaitkan dengan pendapat pribadi Nabi yaitu boleh jadi sabda Nabi tersebut merupakan doa agar pemimpin negeri Persia itu tidak sukses dan boleh jadi hal tersebut merupakan pendapat pribadi Nabi yang didasarkan pada fakta realitas tradisi masyarakat yang pada saat itu tidak memungkinkan bagi

${ }^{15}$ Ali, Nizar, Hadis Versus Sains: Memahami Hadis-Hadis Musykil, Hlm. 118

16 Asse, Ambo, Hadis Ahkam: Ibadah, Sosial dan Politik (Cet. I; Makassar: Alauddin University Press, 2009), Hlm. 204.

17 Syuhudi Ismail, Hadis Nabi Yang Tekstual dan Kontekstual (Cet.I; Jakarta: Bulan Bintang, 1994), Hlm. 67.

Sangaji Jurnal Pemikiran Syariah dan Hukum 
seorang wanita untuk memimpin negara, karena tidak mendapat legitimasi dan tidak dihormati oleh masyarakat jika dipercaya menjadi pemimpin mereka. ${ }^{18}$

Oleh karena itu, Ini berarti hadits di atas harus dipahami secara kontekstual karena memiliki sifat temporal, tidak universal. Hadits tersebut hanya mengungkap fakta yang nyata tentang kondisi sosial pada saat hadits itu terjadi dan berlaku utnuk kasus negara Persia saja dan tidak dimaksudkan sebagai sebuah ketentuan syariat bahwa syarat pemimpin harus laki-laki. Sehingga dengan demikian wanita bisa menjadi pemimpin asalkan bukan pada level pemimpin yang memiliki otoritas mutlak yang membutuhkan syarat laki-laki seperti menjadi imam shalat.

Dari beberapa pernyataan jumhur ulama dan ulama kontemporer di atas, maka adapun posisi penulis dalam makalah ini lebih cenderung berpendapat sama dengan yang dinyatakan oleh ulama kontemporer bahwa hadits di atas harus dipahami secara kontekstual. ${ }^{19}$ Wanita sah-sah saja menjadi pemimpin asalkan memiliki kapabilitas dalam mengemban tugas kepemimpinan. Namun, yang perlu di ingat adalah wanita harus mengingat batasan-batasannya serta tetap menjaga kemaslahatan. ${ }^{20}$

\section{E. Kesimpulan}

1. Islam memandang perihal kepemimpinan berdasarkan kriteria pemimpin yaitu pemimpin harus memiliki sifat

${ }^{18}$ Dikutip dari situs internet http://www.acehinstitute.org. Diakses pada tanggal 10 Mei 2017

${ }^{19}$ Gibtiah, Fikih Kontemporer (Jakarta: Prenadamedia Group, 2016), Hlm. 137.

${ }^{20}$ Penjelasan mengenai hal tersebut dapat dilihat lebih jelas pada kitab Hazim Abdul Muta'ali al-Sa'idi, al-Naz\{ariyah al-Islamiyah fi al-Daulah (Cet.I; Kairo: Dar al-Nahdah al-'Arabiyah, 1397 H/1977 M), Hlm. 195. 
seperti Nabi Muhammad Saw. berupa tabligh, siddiq, amanah dan fathanah dalam menjalankan fungi kepemipinannya.

2. Dalil-dalil mengenai kepemimpinan wanita dapat dipahami melalui beberapa dalil yaitu melalui al Qur'an dan hadits. Dalil al Qur'an yang biasa diperpegangi untuk memberikan pemahaman mengenai kepemimpinan wanita ini adalah melalui QS. Al Nisa ayat 34. Selain itu pemahaman mengenai kepemimpinan wanita mealui hadits dapat dipahami melalui hadits tentang pengangkatan pemimpin di persia yaitu ratu Bintu Kisra.

3. Pandangan ulama terhadap kepemimpinan wanita dalam wilayah publik terdapat perbedaan pendapat, terutama antara ulama klasik dan ulama kontemporer. Ulama klasik lebih menekankan ketidakbolehan wanita menjadi pemimpin karena beberapa alasan termasuk bahwa karena lelaki merupakan pemimpin bagi wanita. Berbeda dengan para ulama klasik, ulama kontemporer memandang bahwa wanita boleh menjadi seorang pemimpin dengan syarat memiliki kapabilitas dalam mengemban tugas kepemimpinan. Namun, yang perlu di ingat adalah wanita harus mengingat batasan-batasannya serta tetap menjaga kemaslahatan.

Sangaji Jurnal Pemikiran Syariah dan Hukum 


\section{Daftar Pustaka}

Abd al-Rauf al-Manawi, Faid \{ al-Qadir , Juz V (Cet. I; Bairut: Dar alKutub al-'Ilmiyah, 1415 H./1994 M)

Abu 'Abdillah Muhammad ibn Isma'il al-Bukhari, shahih alBukhari, Juz. IV (Cet. III; Bairut: Dar Ibn Katsir, 1407 H./1987 M.)

Ambo Asse, Hadits Ahkam: Ibadah, Sosial dan Politik (Cet. I; Makassar: Alauddin University Press, 2009)

Bukhari, Shahih al-Bukhari jil. 8 (Damaskus: Dar al-Kutub alIlmiyah, t.th.)

Gibtiah, Fikih Kontemporer (Jakarta: Prenadamedia Group, 2016) Ibn Hajar al-Asqalani, Tahzib al-Tahzib, Cet. I; Beirut: Dar al-Fikr, 1404 H./1984 M, Juz VII, h. 128.

Imam al-Qurtubi, Al-Jami' li ah\}kam Al Quran jil. 9 (t.t: t.p, t.th.)

Kementrian Agama, Al Quran Translitersi dan Terjemahnya

Dilengkapi Dengan Fadhillah Amal (Bandung: PT. Sygma

Examedia Arkanleema, 2011)

Khalil Abdul Karim, Kontroversi Negara Islam (Surabaya: Nusantara

Press, 2015)

Muhammad ibn 'Ali ibn Muhammad al-Syaukani, Nail al-Autar, Jux VII (Mesir: Mustafa al-Babi al-Halabi, t.t.)

Nizar Ali, Hadits Versus Sains: Memahami Hadits-Hadits Musykil (Cet. I; Yogyakarta: Penerbit Teras, 2008)

Rachmat Ramadhana al-Banjari, Prophetic Leadership (Cet. I; Yogyakarta: Diva Press, 2008)

Syuhudi Ismail, Hadits Nabi Yang Tekstual dan Kontekstual (Cet.I; Jakarta: Bulan Bintang, 1994)

www.acehinstitute.org. Diakses pada tanggal 10 Mei 2017 www.index.php.com. Diakses pada tanggal 10 Mei 2017 